\title{
From Matter to Form Working on Sensorial Qualities of Textile Surfaces
}

\author{
Rossana Carullo ${ }^{1 *}$ and Rosa Pagliarulo ${ }^{2}$ \\ ${ }^{1}$ Department of industrial design, Polytechnic University of Bari, Italy \\ ${ }^{2} \mathrm{PHD}$ in Architectural design, Italy
}

Submission: October 24, 2017; Published: November 27, 2017

*Corresponding author: Rossana Carullo, Coordinator of Course of Industrial Design of Polytechnic University of Bari, Italy, Email: carullorossana@gmail.com; rossana.carullo@poliba.it

Rosa Pagliarulo, Phd in Architectural design at the Polytechnic of Bari, Italy, Email: pagliarulo.rosa@gmail.com

\section{Introduction}

This paper runs a route concerning material and sensorial aspects of textile surfaces.It gathers the results of progressive experimentations on textile surfaces exposed during the New York Textile Month, in September 2016. NYTM was an initiative by Lidewij Edelkoort in collaboration with Cooper Hewitt, Smithsonian Design Museum and Parsons School of design [1]. The work belongs to a wider research which investigates the know-how of Mediterranean heritage, intersecting innovation with tradition, so to built and save our cultural identity in the contemporary globalized world. The aim of the study on textile is to define a contemporary expression of the traditional material process of our region, Apulia, in order to achieve a transcultural comparison. The projects of the textile surfaces arose from manipulation and contamination of materials so to magnify the sensorial, tactile and visual values of surfaces [2-7].

From a methodological point of view, we chose five sensorial categories, which are: softness, smoothness, elasticity, opacity, ductility, and tree actions such as: folding, weaving, stratifying and their endless combinations, in order to differentiate and enhance the sensorial values of textile surfaces, turning the material into expressive form and defining the passage from matter to form [8]. Our method doesn't aim to a finished product. but to identify a rigorous logical process regarding the transformation of materials. Starting to work with easily found materials, we apply the actions of folding, weaving and stratifying [9-11], so to obtain surfaces more or less soft, rough, opaque elastic and ductile, according to five degrees of intensity.

\section{Folding}

Folding introduces to the sequences of the compositional actions on surfaces. The definition of the fold, its depth, its contracted or dilated rhythm, pressed or exploded, its softness or stiffness, its opacity or transparency, are the elements staked to conform the planned surfaces. The aim of the selected projects is to transform the continuous and deaf two-dimensional surface, Figure 1 in a three-dimensional surface able to resound on light and touch.

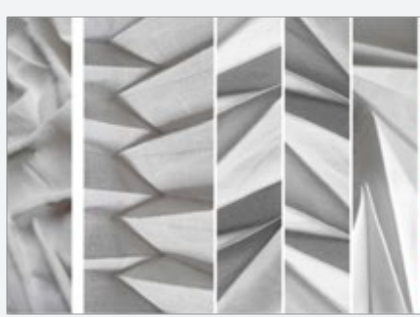

Figure 1: Folding

\section{Weaving}

The works describe the theme of weaving as expression of the structural part of a composition. Surfaces are considered as planes on which represent the principles which control the relationships between the primary elements of the composition: the threads. According to the type of the thread, if natural or synthetic fiber, to the color, homogeneous or not, to the measure,
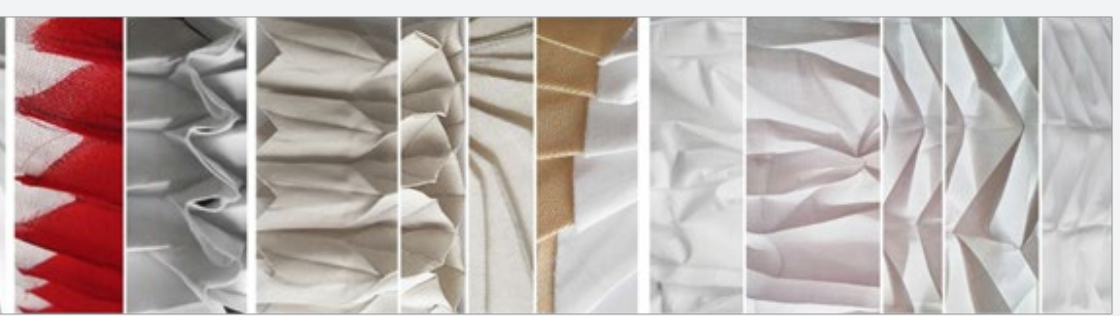

big or small, and to the modes of weave, the composition changes so as the meaning of the work itself and the value of the artifact. The inspiration for the weaving process is linked to the textile know-how of Salento (Puglia). In the textile Laboratory of Le Constantine, established at the beginning of the twentieth century, the ancient weaving decomposes its pattern to become a contemporary expression of sensorial values Figure 2. 


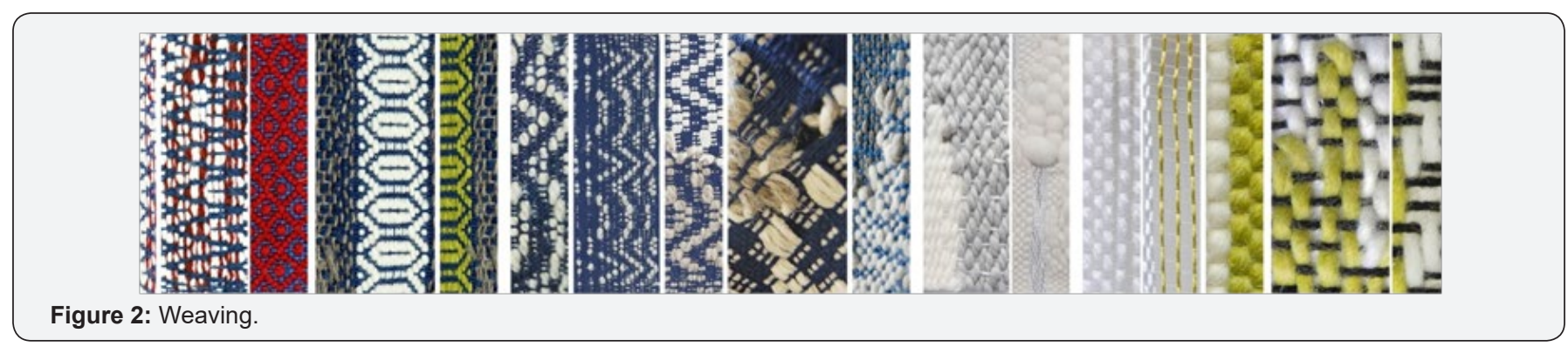

\section{Stratifying}
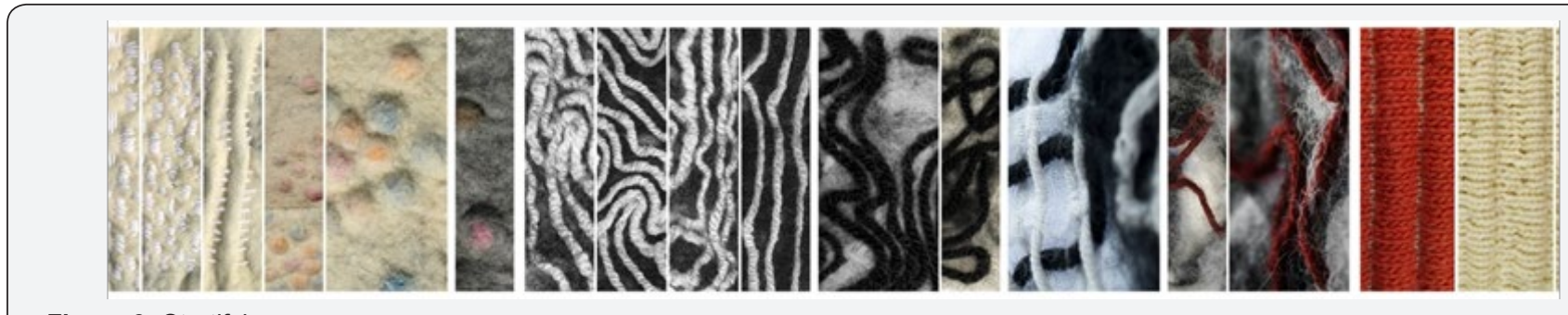

Figure 3: Stratifying

Stratifying regards compositions made by different layers of material. All the layers describe a new condition of the material defined not anymore by the single elements, but by the whole. With the words of Deleuze (1988/1990, p.56), the stratification "does not depend on the parts themselves, but on strata that determine its 'cohesion'. The new status of the object is inseparable from the different layers". Depending on how the single parts of the matter are superimposed and added, and depending on the meaning given to the composition, "the matter becomes matter of expression" (p. 56). The components influencing the formal value of the new statute of the object are the matter and the modality through which such statute is employed. In this research case, the materials taken into consideration have different degrees of softness, and they react to the solicitation of load stretched by another body, bending in its folds, changing conformation, rotating, expanding and varying its own measures. The sensoriality and the will of classification of the values of the surface of the materials are considerations present since a long time in the debate on contemporary design. They are here expressed to make a contribution and to open at the same time new application sectors of the design within the world of interiors Figure 3.

\section{References}

1. Edelkoort L, Fimmano, NYTM New York Textile Month. Talking Textile, Edelkoort Edition, pp 15-19.
2. Dal Curto B, Fiorani E., Passaro C (2010) La pelle del design. Progettare la sensorialità. Lupetti, Milano, Italy.

3. Manzini E (1986) "Fare Elastico epieghevole". In: La materia dell'invenzione, Milano, Italy, pp. 255.

4. Carullo R, Pagliarulo R (2014) Thinking by hands in education. Experimental actions on textile surfaces between interior and design. International Conference Proceeding, Huddersfield, UK.

5. Carullo R, Pagliarulo R (2013) Interior Design. Action on surfaces. International Workshop. Azioni in superficie tra didattica e ricerca, Soveria Mannelli, Rubbettino.

6. Carullo R, Pagliarulo R (2013) Interior-Design: action on surfaces. Softness,Azioni in superficie tra didattica e ricerca, Soveria Mannelli, Rubbettino, 353.

7. Le Breton D (2007) La saveurdu Monde. Uneanthropologie des sens, 2006, In: Raffello C (Ed.), tr. it. Il sapore del mondo. Un’antropologia dei sensi. Milano, Italy, pp. 494.

8. Levi M, Rognoli V (2011) Il senso dei materiali per il design. Franco Angeli, Milano, Italy pp. 272.

9. Deleuze G (1988) Le pli. Leibniz et le baroque tr. it. La piega. Leibniz e il Barocco, Torino, Einaudi.

10. Manzini E (1986) "Dare qualità alla superficie". In: La materia dell'invenzione, Milano, Italy, pp. 255.

11. Riccò D (1999) Sinestesie per il design. Le interazioni sensoriali nell'epoca dei multimedia, Perugia, Etas, pp. 242. 
Your next submission with Juniper Publishers will reach you the below assets

- Quality Editorial service

- Swift Peer Review

- Reprints availability

- E-prints Service

- Manuscript Podcast for convenient understanding

- Global attainment for your research

- Manuscript accessibility in different formats

( Pdf, E-pub, Full Text, Audio)

- Unceasing customer service

Track the below URL for one-step submission https://juniperpublishers.com/online-submission.php 